\title{
STUDIES ON CLINICO-BIOCHEMICAL AND PATHOLOGICAL CHANGES IN THE UREA-INDUCED ACUTE RUMEN ALKALOSIS IN BUFFALO CALVES
}

\author{
S. S. RANDHAWA, P. S. DHALIWAL, P. P. GUPTA, A. K. AHUJA and \\ S. S. RATHOR
}

Department of Veterinary Medicine, College of Veterinary Science, Punjab Agricultural University, Ludhiana 141004, India

Received July 14, 1988

\begin{abstract}
Randhawa S. S., P. S. Dhaliwal, P. P. Gupta, A. K. Ahuja, S. S. Rathor: Studies on Clinico-biochemical and Pathological Changes in the Urea-Induced Acute Rumen Alkalosis in Buffalo Calves. Acta vet. Brno, 58, 1989: 225-243.
\end{abstract}

Peracute rumen alkalosis was induced by intraruminal administration of urea @ $1.25 \mathrm{~g} / \mathrm{kg}$.b.wt. as a single dose in six healthy male Murrah buffalo calves of about $1-2$ years age. Peracute ammonia toxicity resulted in profuse salivation, ruminal stress, incoordination, recumbency followed by clonic convulsions, frequency of which increased with the progression of the condition, dyspnea, hyperpnea, tachycardia, opisthotonus, pupillary dilatation followed by death of the animals between $60-150$ mts. It was observed that a linear relationship exists between death time and body weight of the calf with the same dose rate. Electrocardiographic studies revealed ventricular fibrillation with superimposition of $\mathrm{P}$ wave over $\mathrm{T}$ wave. The cardiac potentials gave rise to random oscillations. Studies on liver function tests revealed that ammonia toxicity markedly affects the functional status of the liver as indicated by increase in serum enzymatic activities of arginase, glutamic oxalotransaminase, glutamic pyruvic transaminase, lactate dehydrogenase and glutamate dehydrogenase with increase in the half life of B.S.P. excretion rate which was subsequently confirmed by histopathological observations. Histopathological changes in the digestive system revealed exfoliation of the epithelial lining of the mucous membrane of the rumen, lymphocytic abomasitis, and necrotic enteritis. Other significant histopathological alterations were follicular cholecystitis, meningo-encephalitis, lymphocytic nephritis and cystitis, and alveolar emphysema.

Intoxication, ECG, rumen liquor, blood, urine

Sudden changes in the dietary constituents with consumption of excess amounts of protein-rich concentrates and/or non-protein nitrogenous compounds has resulted in frequent occurrence of rumen alkalosis in ruminants. The disease is characterised by excessive production of ammonia in the rumen which may produce gastrointestinal, hepatic, renal, circulatory and nervous disturbances (Chalupa 1968; Parkins et al. 
1973; Davidovich et al. 1977; Dave 1980 and Blood et al. 1983). Though clinico-biochemical and pathological studies have been conducted in cattle (Oltjen et al. 1963; Morris and Payne, 1970; Bartley et al. 1976; Davidovich et al. 1977 and Sethuraman and Rathor 1979) but no systematic information is available on the effect of urea-induced ammonia intoxication on hepatic, renal and cardiovascular systems in buffaloes as well as in cattle. Hence the present study was undertaken to investigate and correlate physiological, biochemical and histopathological alterations in experimentally urea-induced rumen alkalosis in buffalo calves.

\section{Materials and Methods}

Six male Murrah buffalo calves of $1-1.5$ years of age were taken for the experimental induction of peracute rumen alkalosis. To establish the zero hour (Normal) values, fasting samples of rumen liquor and blood were simultaneously collected from each animal only once, in the morning hours. Venous blood samples were collected by jugular venipuncture whereas rumen liquor samples were drawn with the help of a stomach tube. The jugular vein was also exteriorised under local anaesthesia for recording central venous pressure (CVP). The CVP was measured with a saline manometer by the method described by Hall (1971). After an overnight fasting, peracute rumen alkalosis was induced in all the six buffalo calves by oral feeding of urea (Fertilizer Grade) @ $1.25 \mathrm{~g} / \mathrm{kg}$ body weight as a single dose. Clinical symptoms of ammonia intoxication were recorded and rumen liquor and blood samples were subsequently drawn from each animal at 30 minutes interval till the animal died. The samples were analysed for the various constituents as described below.

The $\mathrm{pH}$ of rumen liquor and urine was immediately determined with a portable digital $\mathrm{pH}$ meter. Ammonia-N $\left(\mathrm{NH}_{3}-\mathrm{N}\right)$ in rumen liquor, was determined by the microdiffusion technique (Conway 1957). The electrocardiographic (ECG) studies were made with the help of a base-apex electrocardiogram. The heart rate and variations in the duration and amplitude of $P$ wave, QRS complex and $T$ wave and duration of P-R, QT, QoT, QoTc and R-R intervals and S-T segment were analysed in each animal ( $\operatorname{lmV}=1 \mathrm{~cm}$, paper speed $25 \mathrm{~mm}$ per second).

Haemoglobin content of blood was estimated with the help of Erma (Japan) Haemoglobinometer as described by Raymond and Wilkinson (1969). Serum glutamic dehydrogenase (GDH) was estimated as per the method of Bergmeyer (1974). Serum arginase was determined as per the method of Mia and Koger (1978). Serum alanine aminotransferase (ALT) and serum aspartate aminotransferase (AST) were estimated following the method of Reitman and Frankel (1957). Serum lactate dehydrogenase (LDH) activity was determined as per the method described by Wootton (1964). Bromsulphalein dye clearance rate was estimated as per Kaneko and Cornelius (1980). Qualitative physicochemical analysis of representative urine samples was carried out as per Coles (1967). The data were subjected to Student's t-test at 5 per cent level of significance.

All the animals that died during the experiment were autopsied and their tissues were examined histopathologically as per the standard procedures.

\section{Results and Discussion}

The results of biochemical analysis of blood and electrocardiographic studies are presented in Tables 1, 2 and 3.

All the buffalo calves before induction of rumen alkalosis were ruminating, bright, 


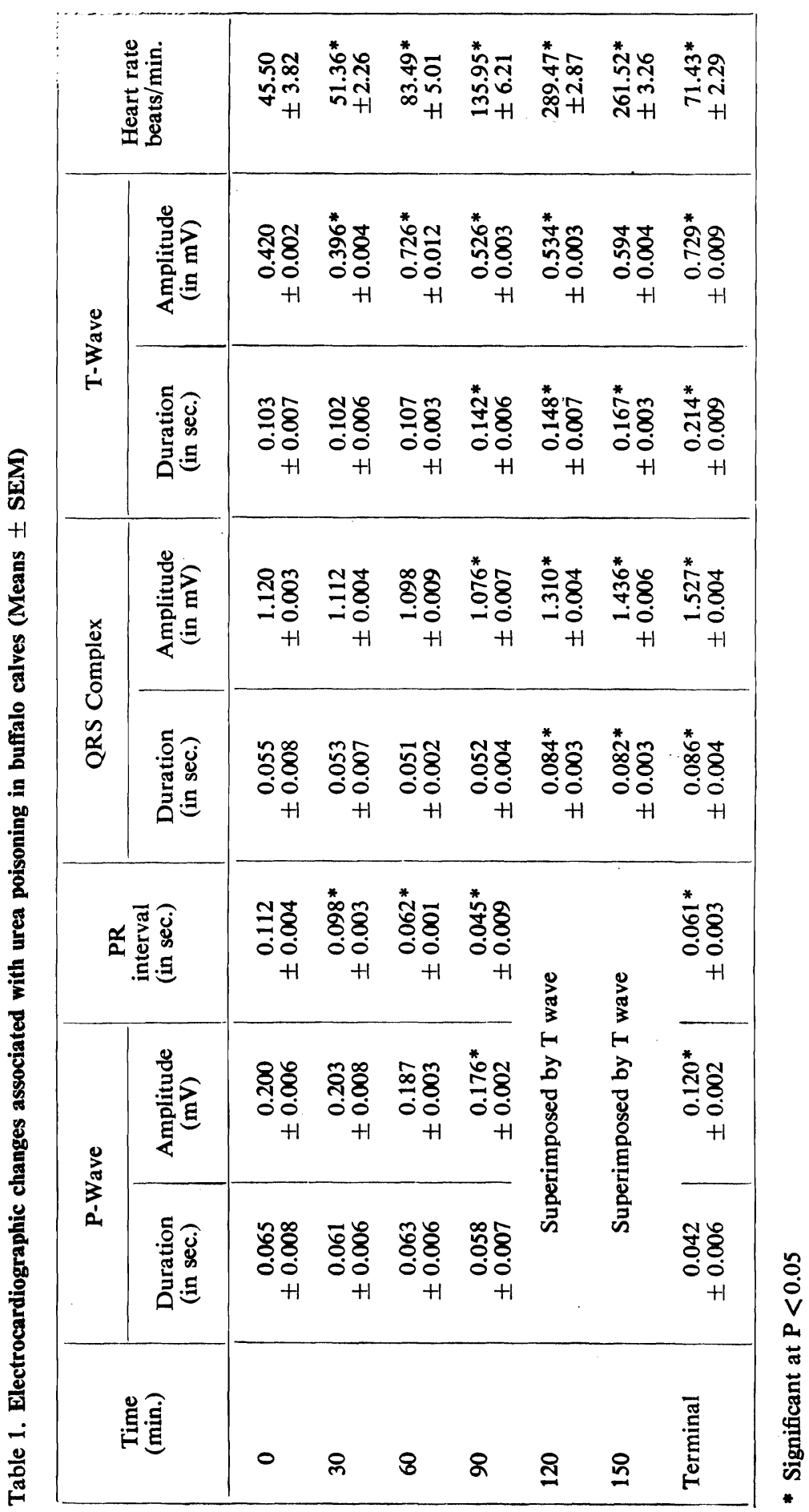


Table 2. Electrocardiographic changes associated with urea poisoning in buffalo calves (Means \pm SEM)

\begin{tabular}{|c|c|c|c|c|c|}
\hline $\begin{array}{c}\text { Time } \\
\text { (in min.) }\end{array}$ & $\begin{array}{l}\text { QoT } \\
\text { interval } \\
\text { (in sec.) }\end{array}$ & $\begin{array}{c}\text { QoTC } \\
\text { interval } \\
\text { (in sec.) }\end{array}$ & $\begin{array}{c}\text { ST } \\
\text { segment } \\
\text { (in sec.) }\end{array}$ & $\begin{array}{c}\mathbf{R}-\mathbf{R} \\
\text { interval } \\
\text { (in sec.) }\end{array}$ & $\begin{array}{c}\text { QT } \\
\text { interval } \\
\text { (in sec.) }\end{array}$ \\
\hline 0 & $\begin{array}{r}0.282 \\
\pm 0.004\end{array}$ & $\begin{array}{r}0.237 \\
\pm 0.003\end{array}$ & $\begin{array}{r}0.212 \\
\pm 0.001\end{array}$ & $\begin{array}{r}1.369 \\
\pm 0.003\end{array}$ & $\begin{array}{r}0.397 \\
\pm 0.001\end{array}$ \\
\hline 30 & $\begin{array}{r}0.278 \\
\pm 0.009\end{array}$ & $\begin{array}{r}0.237 \\
\pm 0.008\end{array}$ & $\begin{array}{r}0.209 \\
\pm 0.006\end{array}$ & $\begin{array}{l}1.168^{*} \\
\pm 0.009\end{array}$ & $\begin{array}{r}0.379 \\
\pm 0.002\end{array}$ \\
\hline 60 & $\begin{array}{ll} & 0.208^{*} \\
\pm & 0.009\end{array}$ & $\begin{array}{r}0.238 \\
\pm 0.005\end{array}$ & $\begin{array}{r}0.126 \\
\pm 0.007\end{array}$ & $\begin{array}{ll} & 0.726^{*} \\
\pm & 0.004\end{array}$ & $\begin{array}{r}0.336 \\
\pm 0.008\end{array}$ \\
\hline 90 & $\begin{array}{r}0.142 \\
\pm / 0.007\end{array}$ & $\begin{array}{r}0.215 \\
\pm 0.004\end{array}$ & $\begin{array}{r}0.080 \\
\pm 0.003\end{array}$ & $\begin{array}{r}0.446 \\
\pm 0.009\end{array}$ & $\begin{array}{r}0.276 \\
\pm 0.004\end{array}$ \\
\hline 120 & $\begin{array}{l}0.086^{*} \\
\pm 0.002\end{array}$ & $\begin{array}{ll} & 0.179 * \\
\pm & 0.003\end{array}$ & $\begin{array}{l}0.052^{*} \\
\pm 0.001\end{array}$ & 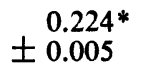 & $\begin{array}{r}0.204 \\
\pm 0.003\end{array}$ \\
\hline 150 & 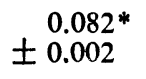 & $\begin{array}{l}0.146^{*} \\
\pm 0.004\end{array}$ & $\begin{array}{l}0^{0.038^{*}} \\
\pm 0.002\end{array}$ & 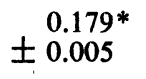 & $\begin{array}{r}0.221 \\
\pm 0.003\end{array}$ \\
\hline Terminal & $\begin{array}{l}0.081^{*} \\
\pm 0.004\end{array}$ & $\begin{array}{l}0.091^{*} \\
\pm 0.003\end{array}$ & $\begin{array}{l} \\
\pm 0.362^{*} \\
0.002\end{array}$ & $\begin{array}{l}0.841^{*} \\
\pm 0.002\end{array}$ & $\begin{array}{r}0.246 \\
\pm 0.009\end{array}$ \\
\hline
\end{tabular}

* Significant at $\mathbf{P}<0.05$.

alert and active. Their mean body temperature, respiration, heart rate and ruminal contractions were within normal range. However, following induction of acute rumen alkalosis, it was observed that the severity and duration of the clinical symptoms was variable depending upon the severity of the ammonia intoxication and was directly related to the body weight of the animal. In general, it was observed that a linear relationship exists between death time and body weight of the urea-intoxicated animal. With the same dose rate of urea administered, it was observed that that the lesser the body weight of the calf, the more intense were the clinical symptoms and shorter was the duration between the onset of the clinical symptoms and death of the calf.

The symptom of slight salivation was observed with no apparent clinical alterations in the physiological functions of cardiovascular, respiratory and nervous systems with mild to moderate decrease in the rate as well as force of ruminal contractions of the animals up to $30 \mathrm{~min}$ after oral administration of urea. However, this was followed by symptoms of marked dullness, depression, reluctance to move, dryness of muzzle, mild to moderate tympany with appearance of muscle tremors particularly of the facial region and hind quarters with twitching of the muzzle and frequent protrusion of the tongue. This was associated with complete loss of rumination, ruminal atony, frequent micturition though in small quantity and intense ocular congestion. In majority of the calves, furious look with pressing of the head against wall and tendency to rush forward with moistness of the muzzle at this stage was also observed. Subsequently animals became extremely weak and were unable to support their body. Symptoms of incoordinated gait were followed by sternal re- 
Table 3. Biochemical changes in the blood in urea induced rumen alkalosis (Means \pm SEM)

\begin{tabular}{|c|c|c|c|c|c|c|}
\hline \multirow{2}{*}{ Parameters } & \multicolumn{6}{|c|}{ Time of sampling (min) } \\
\hline & 0 & 30 & 60 & 90 & 120 & 150 \\
\hline Arginase (IU/L) & $\begin{array}{r}2.16 \\
\pm 0.70\end{array}$ & $\begin{array}{l}{ }^{8.08 *} \\
\pm 1.04\end{array}$ & $\begin{array}{l}13.00^{*} \\
\pm 2.03\end{array}$ & $\begin{array}{l}15.80^{*} \\
\pm 2.88\end{array}$ & $\begin{array}{l}19.66^{*} \\
\pm 5.18\end{array}$ & $\begin{aligned} & 20.00^{*} \\
& \pm 1.00\end{aligned}$ \\
\hline SGOT (U/L) & $\begin{array}{r}30.17 \\
\pm 2.08\end{array}$ & $\begin{array}{r}34.76 \\
\pm 1.35\end{array}$ & $\begin{array}{l}37.47^{*} \\
\pm 1.35\end{array}$ & $\begin{array}{c}39.71 * \\
\pm 1.30\end{array}$ & $\begin{array}{c}42.68^{*} \\
\pm 2.66\end{array}$ & $\begin{array}{c}44.47^{*} \\
\pm 4.81\end{array}$ \\
\hline SGPT (U/L) & $\begin{array}{r}16.81 \\
\pm 1.06\end{array}$ & $\begin{array}{r}21.73 \\
\pm 1.57\end{array}$ & $\begin{array}{r}21.87 \\
\pm 3.55\end{array}$ & $\begin{array}{r}29.89 \\
\pm 6.24\end{array}$ & $\begin{array}{r}38.45^{*} \\
\pm 4.67\end{array}$ & $\begin{array}{r}33.37 \\
\pm 6.41\end{array}$ \\
\hline LDH (IU/L) & $\begin{array}{r}378.92 \\
\pm 6.62\end{array}$ & $\begin{array}{l}406.06 \\
\pm 8.94\end{array}$ & $\begin{array}{c}436.39 * \\
\pm 11.22\end{array}$ & $\begin{array}{l}470.77^{*} \\
\pm 7.64\end{array}$ & $\begin{array}{l}479.12^{*} \\
\pm 7.79\end{array}$ & $\begin{array}{l}496.85^{*} \\
\pm 0.72\end{array}$ \\
\hline GDH (U/L) & $\begin{array}{r}1.09 \\
\pm 0.16\end{array}$ & $\begin{array}{l}3.30^{*} \\
\pm 0.27\end{array}$ & $\begin{array}{l}4.80^{*} \\
\pm 0.34\end{array}$ & $\begin{array}{l}7.15^{*} \\
\pm 0.79\end{array}$ & $\begin{array}{l}9.66^{*} \\
\pm 0.41\end{array}$ & $\begin{array}{l}10.50^{*} \\
\pm 0.65\end{array}$ \\
\hline $\begin{array}{l}\text { B.S.P. (T1/2 value) } \\
\text { (min. }\end{array}$ & $\begin{array}{r}5.37 \\
\pm 1.05\end{array}$ & - & - & $\begin{array}{l}13.92^{*} \\
\pm 3.00\end{array}$ & - & - \\
\hline $\mathrm{Hg}(\mathrm{gm} \%)$ & $\begin{array}{r}11.70 \\
\pm 0.31\end{array}$ & $\begin{array}{l}10.65^{*} \\
\pm 0.14\end{array}$ & $\begin{array}{r}11.52 \\
\pm 1.33\end{array}$ & $\begin{array}{r}10.95 \\
\pm 0.16\end{array}$ & $\begin{array}{r}11.36 \\
\pm 1.00\end{array}$ & $\begin{array}{r}13.05 \\
\pm 1.09\end{array}$ \\
\hline $\operatorname{PCV}(\%)$ & $\begin{array}{r}32.57 \\
\pm 0.92\end{array}$ & $\begin{array}{r}31.00 \\
\pm 1.03\end{array}$ & $\begin{array}{r}30.60 \\
\pm 1.28\end{array}$ & $\begin{array}{r}33.25 \\
\pm 1.29\end{array}$ & $\begin{array}{r}34.33 \\
\pm 1.18\end{array}$ & $\begin{array}{r}36.50 \\
\pm 2.47\end{array}$ \\
\hline No. of animals & 6 & 6 & 5 & 5 & 3 & 2 \\
\hline
\end{tabular}

* Significant at $\mathbf{P}<0.05$.

cumbency. The occasional clonic convulsions were observed immediately after the onset of recumbency, the frequency of which increased with the progression of the condition. At this stage, no salivation was observed. Animals were in opisthotonus condition and strong paddling movements of limbs with marked pupillary dilatation was observed. Convulsive phase was associated with hypersensitivity to external stimuli, nystagmus, muscle rigidity, stiffness of neck, tachycardia, dyspnea and hyperpnea with frequent dribbling of urine. Terminally, the animals were in lateral recumbency with frequent occurrence of tonic convulsions, absence of eye reflex and complete pupillary dilatation. Gasping respiration with dilatation of nostrils but with marked decrease in respiratory rate was observed. Animals were not responding to external stimuli ending with their death at this stage. These clinical findings are similar to those reported by Chalupa 1968; Bartley et al. 1976; Davidson et al. 1977 and Choudhuri et al. 1981. It was observed that intensity and duration of symptoms in the buffalo calves appeared to be longer though with delayed onset as compared to other species of animals which is similar to the observations of Dave (1980).

The degree of manifestation of clinical symptoms in the present study was related to the concentration of ammonia in the rumen as well as blood which is similar to 
the observations of Bartley et al. (1976) and Davidovich et al. (1977). The findings of Chalupa (1968) that the difference in the duration of the clinical symptoms might be related to the difference in the blood ammonia levels attained at each stage of the disease also confirms the present observations. The comparatively longer time taken for manifestation of clinical symptoms in buffalo calves even after oral administration of urea at a much higher dose (Induction @ $1.25 \mathrm{~g} / \mathrm{kg}$ body weight) in the present study is contrary to the observations of other workers (Bartley et al. 1976 in cattle - induction @ $0.5 \mathrm{~g} / \mathrm{kg}$ body weight) but similar to those of Dave (1980) reported in buffalo calves. This indicates that the ammonia utilization in buffaloes may be more efficient with a higher tolerance limit as compared to cattle (Misra and Rahhotra 1969).

The onset of ruminal atony observed in the present study could be ascribed to the significant increase in $\mathrm{pH}$ and ammonia levels of the rumen liquor (Clark et al. 1951 and Smith 1969). Hyperglycaemia and hyperammonaemia observed in the present investigation associated with increased accumulation of toxic amines (Verma and Ganapathy 1973) and hypomagnesemia (Bueno et al. 1977) and increased butyrate concentration are also considered to be responsible for the inhibition of ruminal contractions (Svendsen 1973). Similarly, it has been reported that complete ruminal atony and ruminal paralysis was observed following intravenous administration of ammonia but no effect was observed on intraruminal infusion of ammonium salts suggesting the role of increased ammonia levels in the blood and cerebrospinal fluid, in directly inhibiting the central nervous system, controlling the ruminal contractions (Clark et al. 1951; Setia et al. 1980). The neurological symptoms observed in the present study are considered to be due to effect of ammonia in decreasing the magnitude and potency of inhibitory post-synaptic potentials in the central nervous system and subsequent sequence of biochemical changes as suggested by L ux (1971). Similarly, shunting of ammonia across the liver to systemic circulation and the associated changes in the cellular energy metabolism depleting the brain energy stores (Chalupa 1972) might also account for the biochemical basis for the genesis of neurological signs. Some of these postulations have been confirmed by electroencephalographic studies (Setia et al. 1980) and following the detailed biochemical (Choudhuri et al. 1981), histological and histoenzymological studies of the nervous system in the present investigation.

A gradual and significant increase in ruminal $\mathrm{pH}$ was recorded from the initial value of $7.15 \pm 0.08$ to $8.18 \pm 0.14$ at $90 \mathrm{~min}$ of induction of ruminal alkalosis. Thereafter, there was a slight decrease at $2 \mathrm{~h}$ postinduction but values were still significantly higher than the base value. In the present study, the ammonia intoxication symptoms were observed when the $\mathrm{pH}$ of rumen liquor reached above 8.0. Increase in the $\mathrm{pH}$ of rumen liquor could be ascribed to poor buffering capacity of the rumen fluid against the addition of alkali (Turner and Hodgetts 1955).

Physical characteristics and consistency viz. color of urine samples were not significantly changed throughout period of experimental observation. Urine samples following induction of urea toxicity imparted ammoniacal odour throughout the period of observation. Urine $\mathrm{pH}$ showed a gradual and significant increase from $7.94 \pm 0.09$ to $9.58 \pm 0.16$ by mid of induction followed by restoration of the $\mathrm{pH}$ towards normal level. Initial increase in the urine $\mathrm{pH}$ was possibly due to increased excretion of $\mathrm{NH}_{3}-\mathrm{N}$ in the urine and subsequent decrease could be ascribed to the onset of severe form of metabolic acidosis observed in terminal stages causing shift in the $\mathrm{pH}$ values towards normal range.

Qualitative biochemical analysis of urine samples revealed presence of albumin in traces in terminal stages whereas glucose, ketone bodies, bile salts, blood and bile 
pigments were not detected throughout the period of experimental observation. The detection of albumin in traces confirmed the earlier observations of Singer and McCarty (1971) and Dave (1980) which indicated low grade damage to kidney parenchyma following ammonia toxicity. This was confirmed subsequently by histopathological and histoenzymological alterations of the kidneys recorded in the present study.

The average value of packed cell volume of blood increased from $32.57 \pm 0.92$ to $36.50 \pm 2.47$ per cent at $150 \mathrm{~min}$ of induction. This is similar to the observations of Lloyd (1970) and Davidovich et al. (1977). The increase in packed cell volume could be ascribed to acute degree of stress associated with urea intoxication resulting in release of stored erythrocytes into the peripheral circulation probably due to
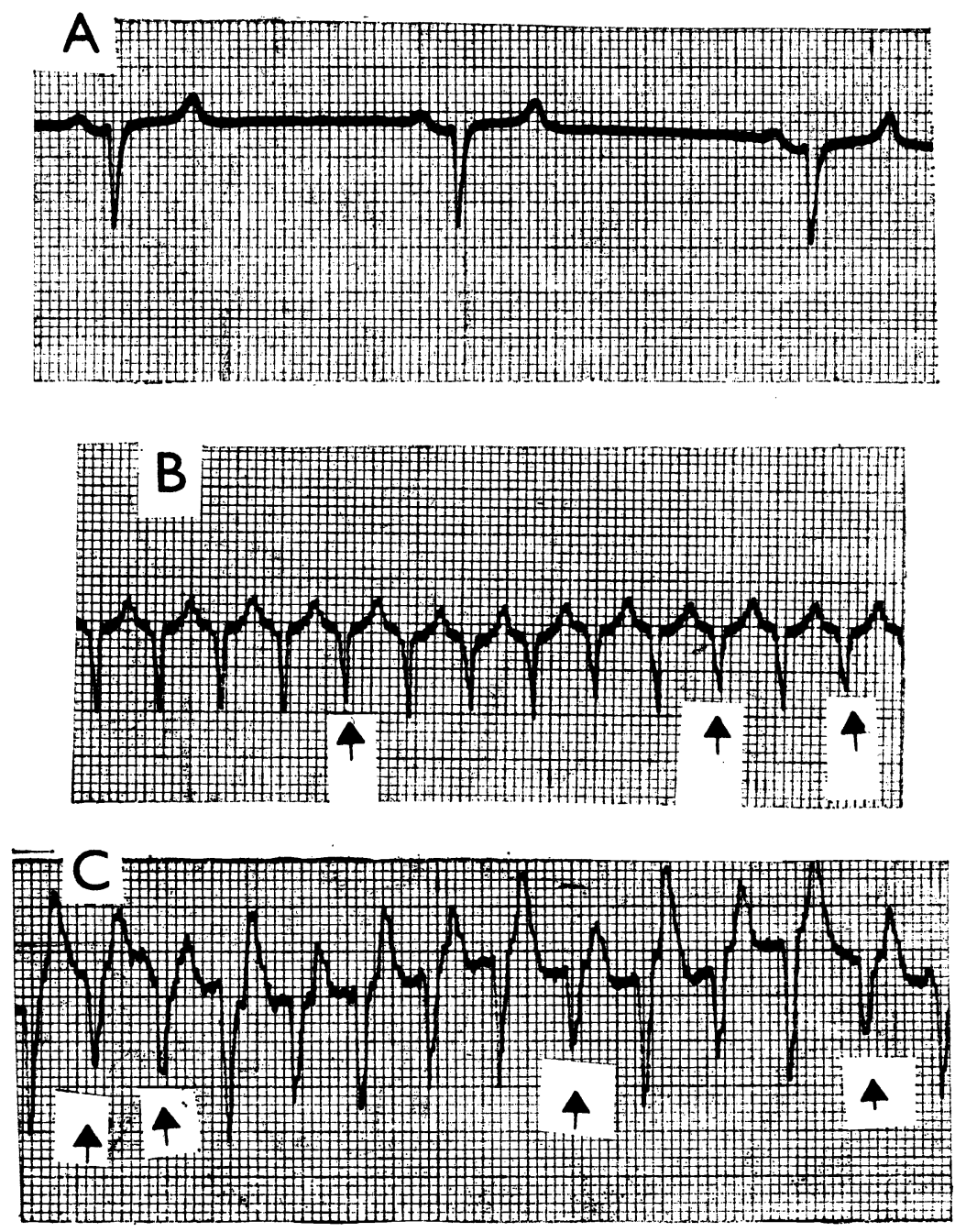

Fig. 1. Electrocardiographic changes in urea induced rumen alkalosis in buffalo calves. $\mathbf{A}$ - Normal electrocardiogram, B - Marked tachycardia $\uparrow$ (heart rate more than 250 beats per minute, C - Cardiac arrhythmias $(\uparrow)$ with premature heart beats. 

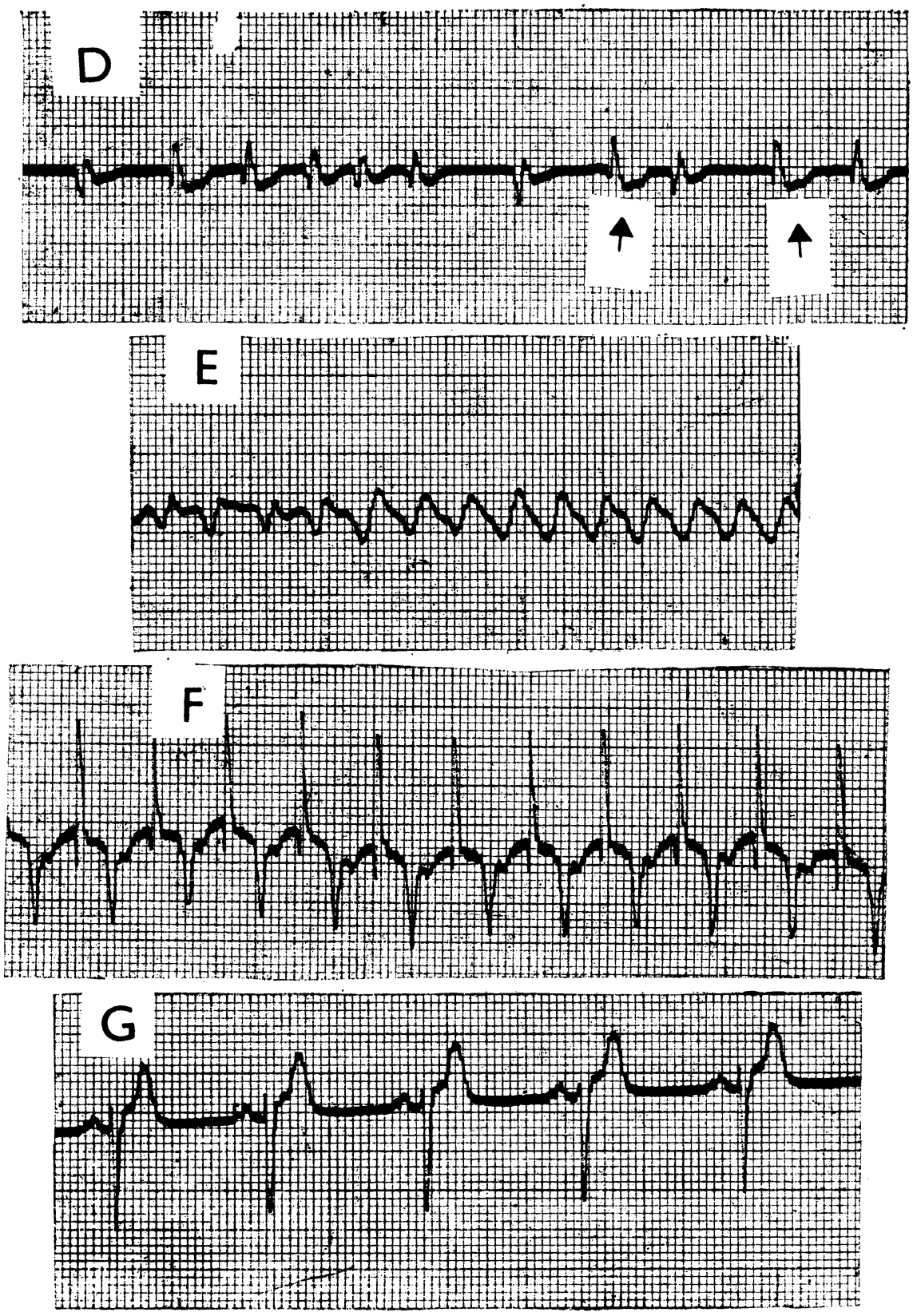

Fig. 2. Electrocardiographe changes in urea induced rumen alkalosis in buffalo calves. D - Cardiac arrhythmias without proper repolarising sequence ( $\uparrow$ T-waves), E - Ventricular fibrillation, $F$ - 0 Increased amplitude of QRS complex and T waves, $G$ - Slow-down of heart rate with broad and tall $\mathrm{T}$ waves leading to cardiac asystole (terminal). 
splenic contractions. The average concentration of haemoglobin showed a non-significant alteration from $11.70 \pm 0.31$ to $13.05 \pm 1.09 \mathrm{~g} \%$ of $150 \mathrm{~min}$. However, analysis of the haemoglobin content of the individual animal revealed that generally before death of the buffalo calves due to urea intoxication, the haemoglobin content always showed a significant increase in all the animals. This increase in the haemoglobin content might be due to increase in the packed cell volume observed in the present investigation.

The electro-cardiographic studies revealed that heart rate increased from base value of $45.50 \pm 3.82$ to $261.74 \pm 3.06$ beats $/ \mathrm{min}$ by $150 \mathrm{~min}$ following induction of rumen alkalosis (Fig. 1; B). The mean CVP recorded in four of the healthy calves was $4.17 \mathrm{~cm} \mathrm{H} \mathrm{H}_{2} \mathrm{O}$ which increased to more than $20.00 \mathrm{~cm}$ terminal stages of urea toxicity. Significant decrease in the blood pressure has been recorded in ammonia toxicity in crossbred calves (Setia et al. 1980). The correlation of tachycardia with a fall in arterial pressure and significant increase in central venous pressure in ammonia toxicity suggested that there was vascular pooling and venodilation or a decrease in the cardiac output. Intense redness of the skin observed with the convulsive phase on visual inspection is also suggestive of vasodilation and vascular pooling. All the buffalo calves developed ventricular fibrillation in terminal stage (Fig. 2; F). There were no recognizable $\mathbf{P}$ waves or $\mathrm{QRS}$ complexes. The cardiac potentials gave rise to random oscillations. The duration and amplitude of $P$ wave was markedly decreased whereas that of $T$ wave was significantly increased following ammonia intoxication (Fig. 2; E, G). It is possible that the circulating ammonia might get accumulated in the cardiac muscles (Kirkpatrick et al. 1972); thereby inducing tachycardia and raising of $T$ waves (Callanan et al. 1974; Sugawara and Sasaki 1972). The duration of QT, QoT and QoTC interval showed a decreasing trend throughout the period of experimental induction. A gradual decrease was observed in the PR and R-R intervals. Similarly, significant decrease was observed in the ST segment duration following induction of ammonia toxicity. Cardiac arrhythmias with premature heart beats were observed (Fig. 1; C). Terminally, slowing of heart rate with broad and tall $\mathrm{T}$ waves leading to cardiac asystole was observed (Fig. 2; H).

Injury to the liver, due to abnormal rumen metabolism as a result of urea feeding (Blood et al. 1983) and high protein intake (Hoflund 1967) have been reported, the basis of their diagnosis being clinical and necropsy findings. Whereas studies on enzymes related with hepatic dysfunctions due to rumen alkalosis are scarce (Alikutty 1981).

The increase in concentration of various serum enzymes in the circulation occur as a result of their escape from the disrupted hepatic cells with necrosis or altered membrane permeability of the cells.

In the present investigation a combination of two types of liver function tests, i.e. tests measuring serum enzyme activity and tests measuring the hepatic transport (uptake, conjugation and excretion) of foreign dye have been used to assess the extent of liver damage, which has been subsequently confirmed by histopathological and histoenzymological studies. Activities of both liver specific enzymes viz., arginase, alanine aminotransferase and glutamate dehydrogenase as well as those not specific for liver viz., aspartate aminotransferase and lactate dehydrogenase have been estimated. Enzyme arginase showed a significant increase during the course of experimental rumen alkalosis. The preinduction level of $2.16 \pm 0.70 \mathrm{IU} / \mathrm{L}$ increased significantly to a value of $20.00 \pm 1.00 \mathrm{IU} / \mathrm{L}$ at $150 \mathrm{~min}$ post induction i.e. just before death which was about 10 times the base value. This increase in level and the histopathological findings of cloudy swelling of hepatocytes strongly suggest the 
evidence of liver damage caused by hyperammonaemia. Similar observations have been reported by Cornelius et al. (1963) and Kaneko and Cornelius (1980).

The pre-induction levels of aminotransferases were similar to those observed by Neduncheralathen et al. (1984). Though there was a gradual increase in the level of alanine aminotransferase (SGPT) from $16.81 \pm 1.06 \mathrm{IU} / \mathrm{L}$ to a peak of $38.45 \pm 4.67 \mathrm{U} / \mathrm{L}$ at 120 minutes, yet this increase remained insignificant throughout the experiment except at $120 \mathrm{~min}$. Since, the liver of large domestic animals do not contain significant levels of SGPT, only very small elevations of SGPT enzyme occurs from hepatic damage in these animals (Ka ne co and Cornelius 1980). Enzyme aspartate aminotransferase (SGOT) increased from a pre-induction level of $30.17 \pm$ $2.08 \mathrm{U} / \mathrm{L}$ significantly from $60 \mathrm{~min}$ interval to a peak of $44.47 \pm 4.81 \mathrm{U} / \mathrm{L}$ at 150 min sample. Since many body organs like heart and kidneys, contain high concentrations of this enzyme, the above mentioned findings of elevated SGOT levels due to hepatic damage have to be differentiated from diseases affecting other organs. This has been confirmed by estimation of other liver specific enzymes, BSP clearance rate of liver and clinical symptoms (Ross 1967).

Among the dehydrogenases, glutamate dehydrogenase enzyme, specific for the liver maintained a continuous increase from pre-induction level of $1.09 \pm 0.16 \mathrm{U} / \mathrm{L}$ to a peak of $10.50 \pm 0.65 \mathrm{U} / \mathrm{L}$ just before death. It started rising in the serum from the very first sampling time $(30 \mathrm{~min})$ and showed an increase of about 10 times till death $(150 \mathrm{~min})$. Similar trend was shown by enzyme lactate dehydrogenase, starting from a pre-experimental value of $378.92 \pm 6.62 \mathrm{U} / \mathrm{L}$ which reached a significant level at $60 \mathrm{~min}$ interval and by $150 \mathrm{~min}$ time it reached a peak of $496.85 \pm$ $0.72 \mathrm{U} / \mathrm{L}$. These findings are similar to those reported by Johnson (1978). These increases in the serum have been confirmed by histoenzymic studies conducted on the animals dying during the experiment.

Bromsulphalein dye clearance rate of the liver is among the most sensitive indicators of hepatic dysfunctions. In the experimental rumen alkalosis, the half life

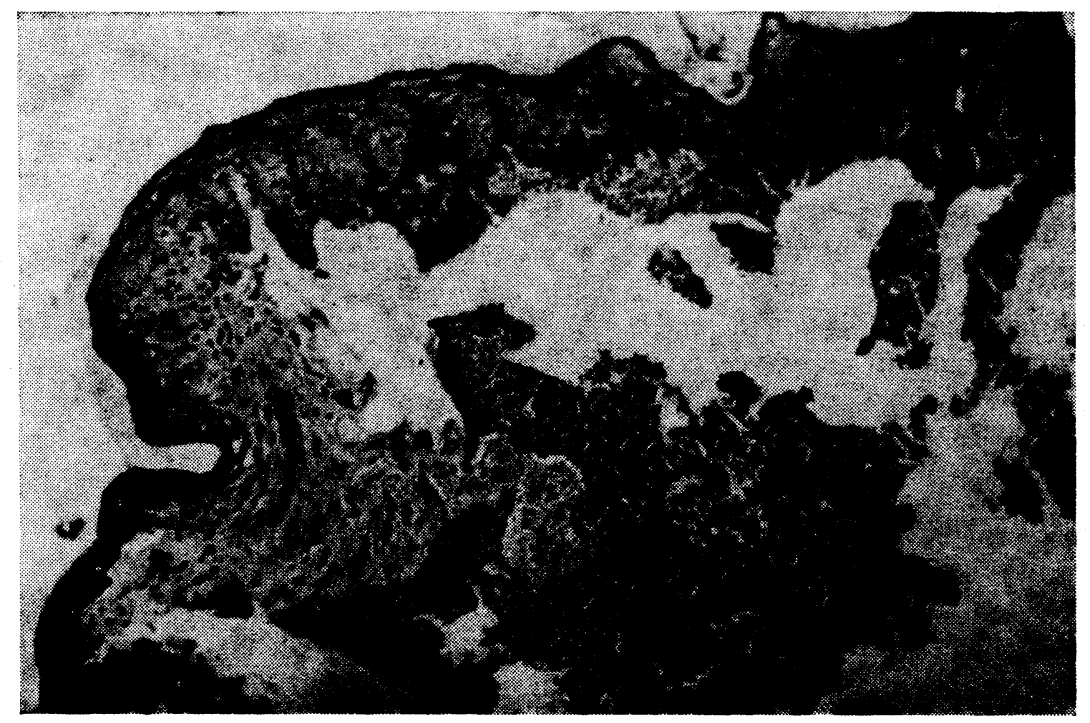

Fig. 3. Section of rumen mucosa showing exfoliation of mucosa, oedema in lamina propria and hydropic degeneration in the epithelial cells. H. \& E. $\times 70$. 


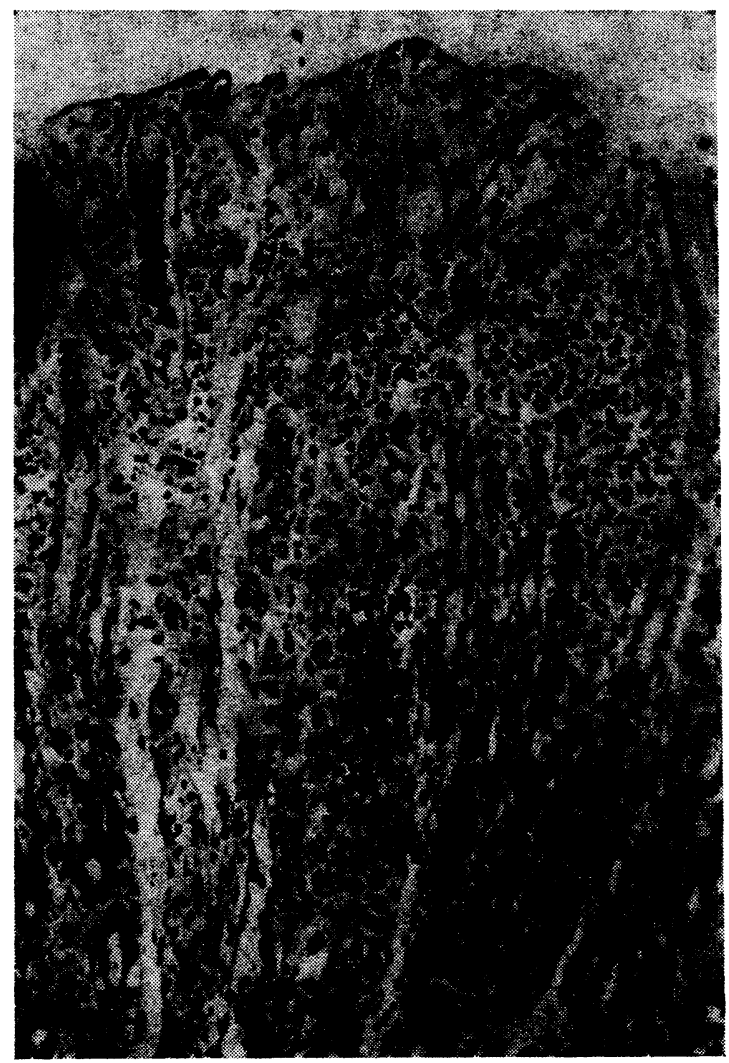

Fig. 4. Section of abomasum showing lymphocytic abomasitis. H. \& E. $\times 70$.

(T0.5) of BSP in blood plasma was estimated at the pre-induction stages and then just before death i.e. at 90 minutes in two animals and at $120 \mathrm{~min}$ in three animals. The mean half life of BSP dye showed a significant prolongation from $5.37 \pm 1.05$ $\min$ to $13.92 \pm 3.00 \mathrm{~min}$ just before death. This change can very well be attributed to hepatic insufficiency with loss of excretory function of liver as a result of rumen alkalosis (Alikutty 1981 and Korsai and Sehafer 1984) caused by toxic effect of ammonia on bile canalicular system which has been confirmed by histoenzymic study which showed a marked loss of alkaline phosphatase activity in bile canaliculi.

Intense hyperaemia of the rumen mucosa was observed which imparted characteristically deep pinkish red colouration. Exfoliation and detachment of the rumen mucosa was noticed particularly involving dorsal sac of the rumen. However, no gross lesions were observed in the reticulum. The rumen contents were fluid in consistency which imparted ammonical odour. Omasum was hard and its contents were dry. Marked congestion of the intestinal mucosa was seen with submucosal haemorrhagic patches. The abomasum, liver and kidneys revealed mild to moderate degree of congestion and swelling was also observed in kidneys. An examination of brain revealed intense degree of congestion. The haemorrhagic lesions mainly in the form of petechial haemorrhage were observed in the heart. However, macroscopic examination of other organs did not reveal any significant lesions. 


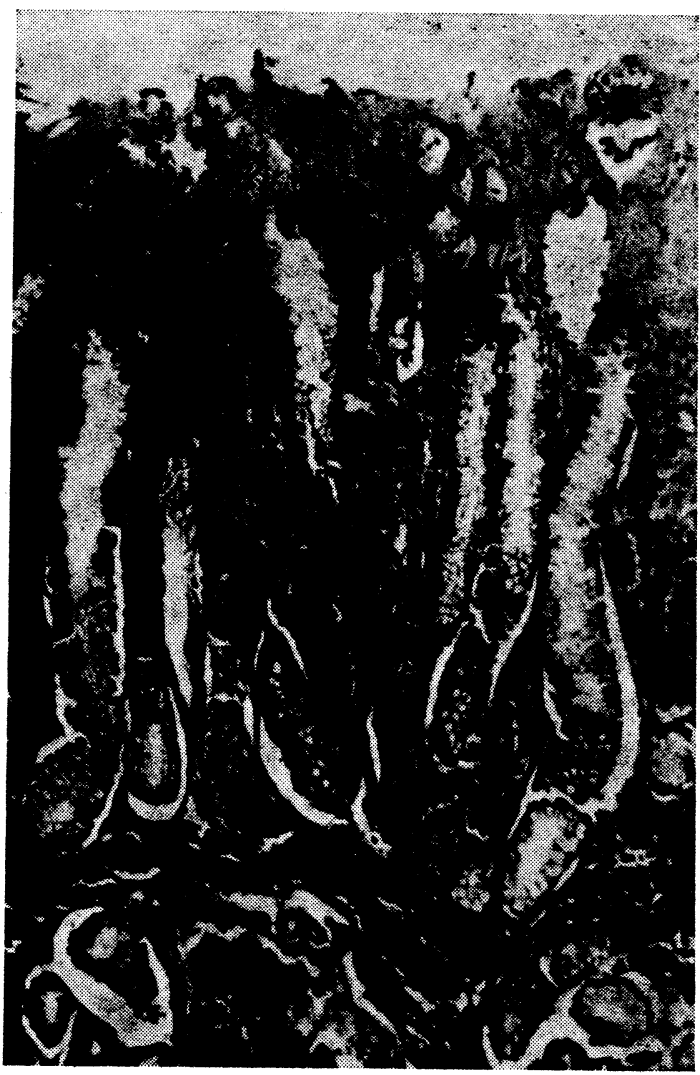

Fig. 5. Section of intestine showing necrotic enteritis. H. \& E. $\times 70$.

Histopathological changes in the digestive system were hydropic degeneration and exfoliation of the epithelial lining of the mucous membrane and oedema in the lamina propria of rumen (Fig. 3) and lymphocytic abomasitis (Fig. 4). Small intestine revealed necrotic enteritis characterised by necrosis of tips of villi (Fig. 5), congestion of blood vessels, haemorrhage and desquamation of villi.

On examination, the liver showed intense cloudy swelling of hepatocytes and marked swelling of the wall of hepatic arterioles leading to narrowing of their lumina, gall bladder showed follicular cholecystitis characterised by the formation of lymphoid follicles in the lamina propria (Fig. 6) and necrosis and exfoliation of the epithelium lining of the mucous membrane.

The examination of brain revealed meningoencephalitis characterised by infiltration of lymphocytes in the meninges and in perivascular Virchow-Robin spaces (Fig. 7), chromatolysis, satellitosis, neuronophagia, gliosis (Fig. 8) and necrosis of Purkinje cells in the cerebellum (Fig. 9). There was marked congestion and haemorrhages in the perivascular spaces (Fig. 7).

The kidneys showed congestion, haemorrhages and lymphocytic infiltration in the interstitial tissues (Fig. 10). The tubular epithelium revealed variable degree of degenerative changes with presence of tubular casts.

The examination of lungs revealed congestion, haemorrhages and alveolar emphysema (Fig. 11). 


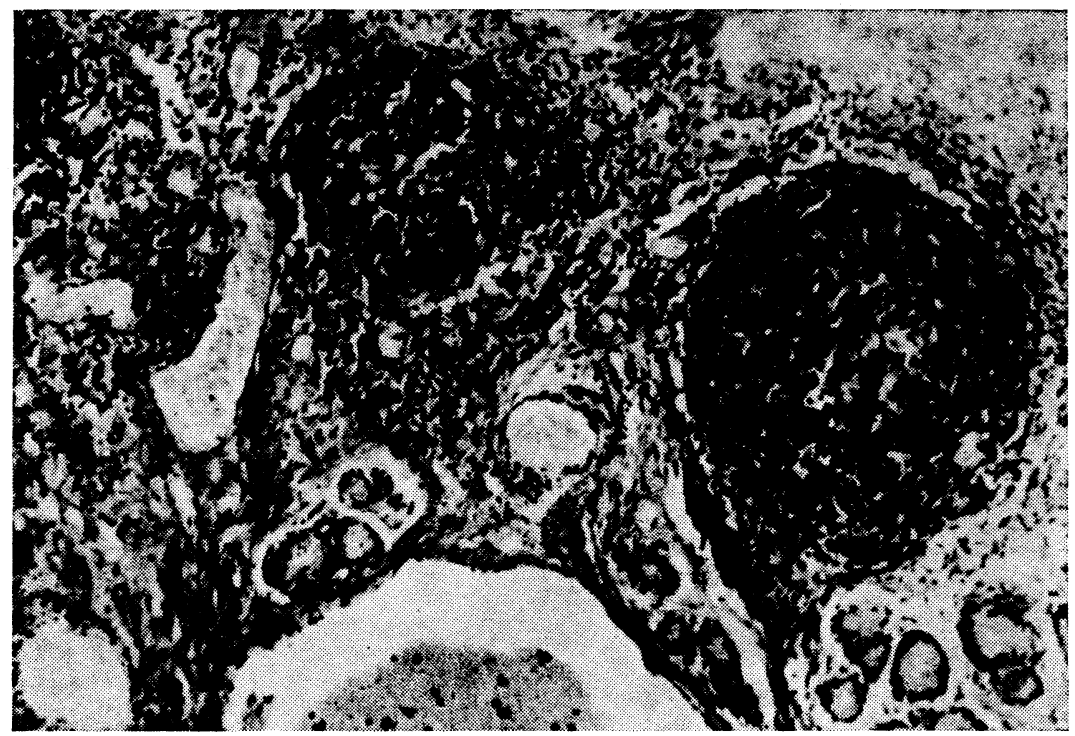

Fig. 6. Section of gall bladder showing follicular cholecystitis. H. \& E. $\times 70$.

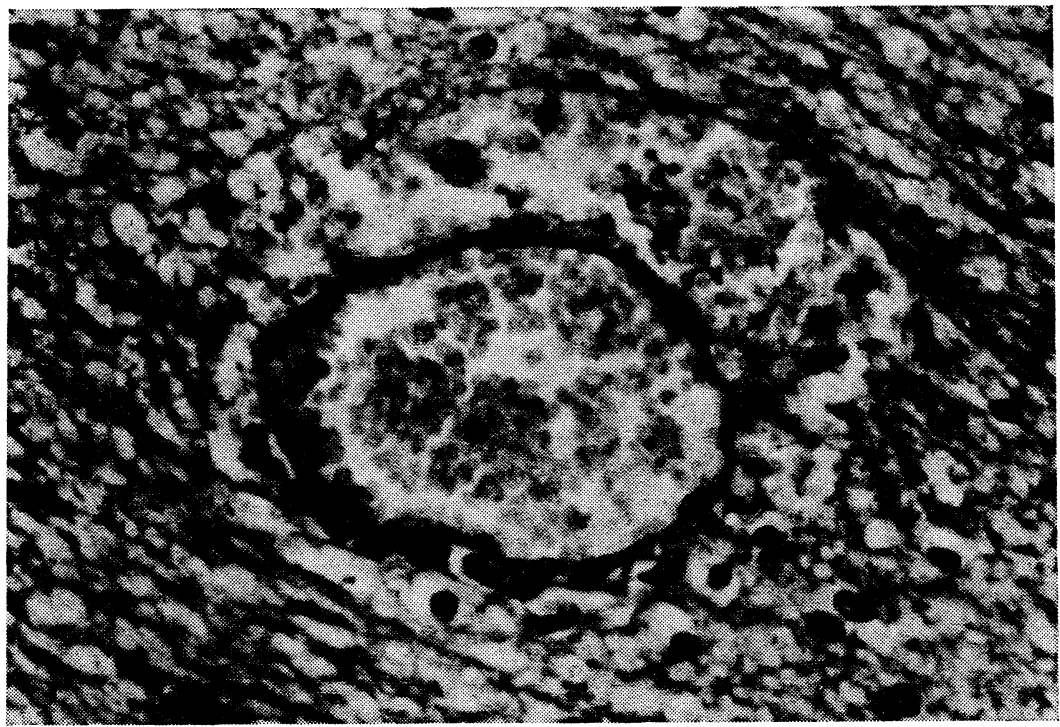

Fig. 7. Section of brain showing perivascular haemorrhage and infiltration of lymphocytes and intense congestion. H. \& E. $\times 70$. 


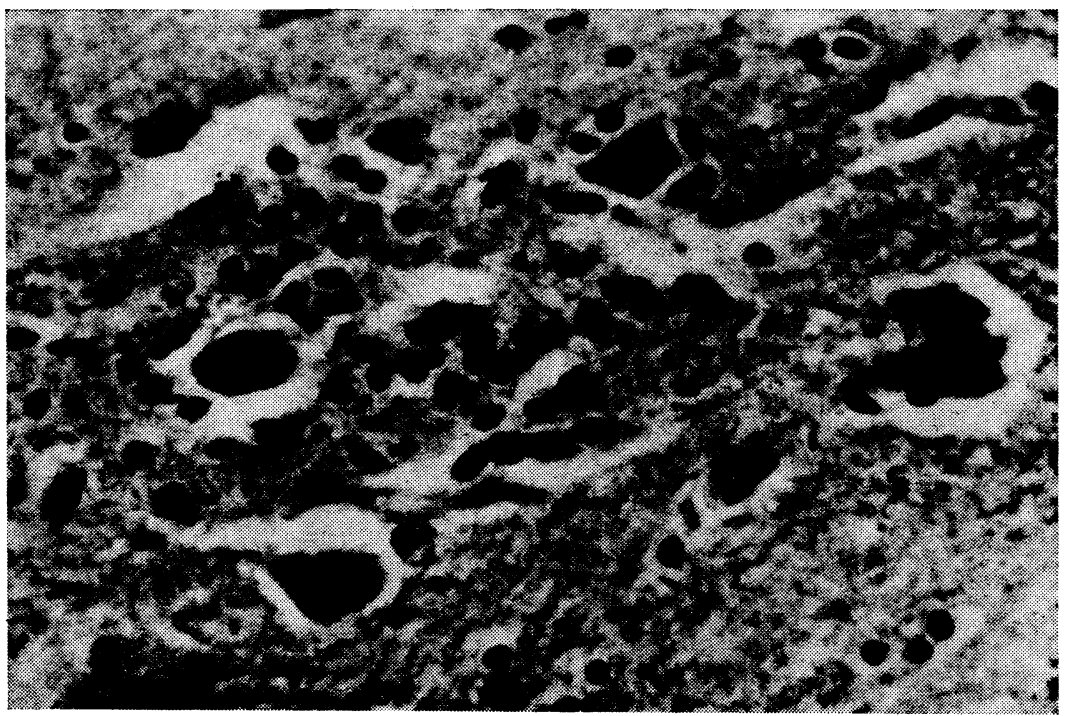

Fig. 8. Section of brain showing satellitosis, neuronophagia and gliosis. H. \& E. $\times 70$.

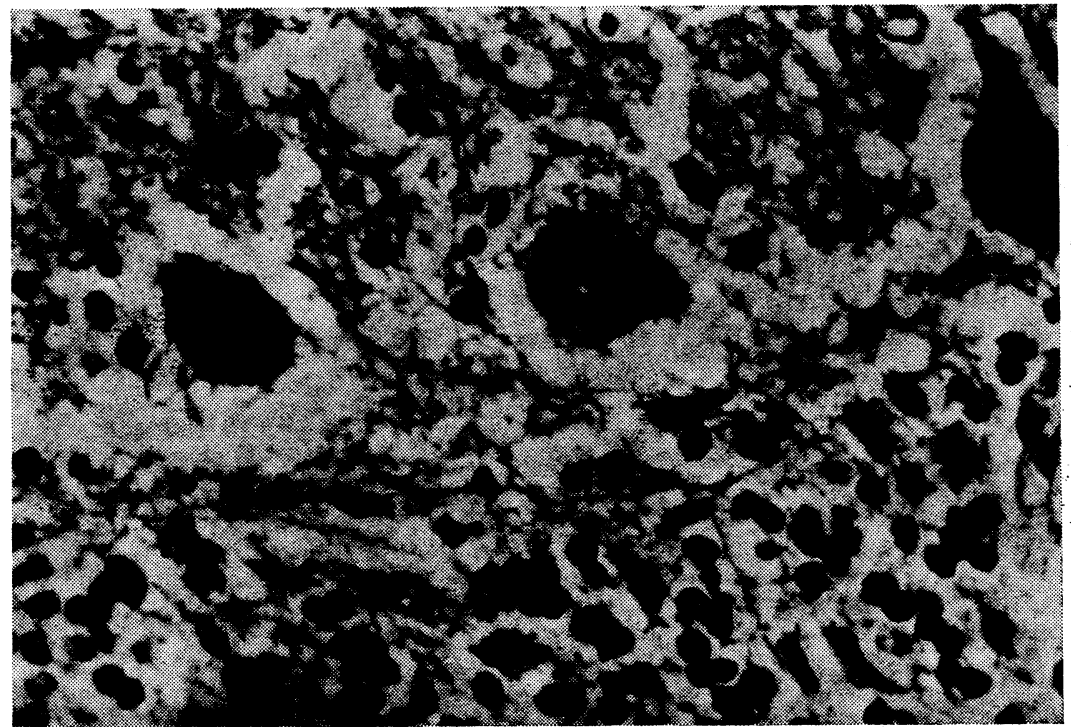

Fig. 9. Section of cerebellum showing necrosis of Purkinje cells. H. \& E. $\times 300$. 


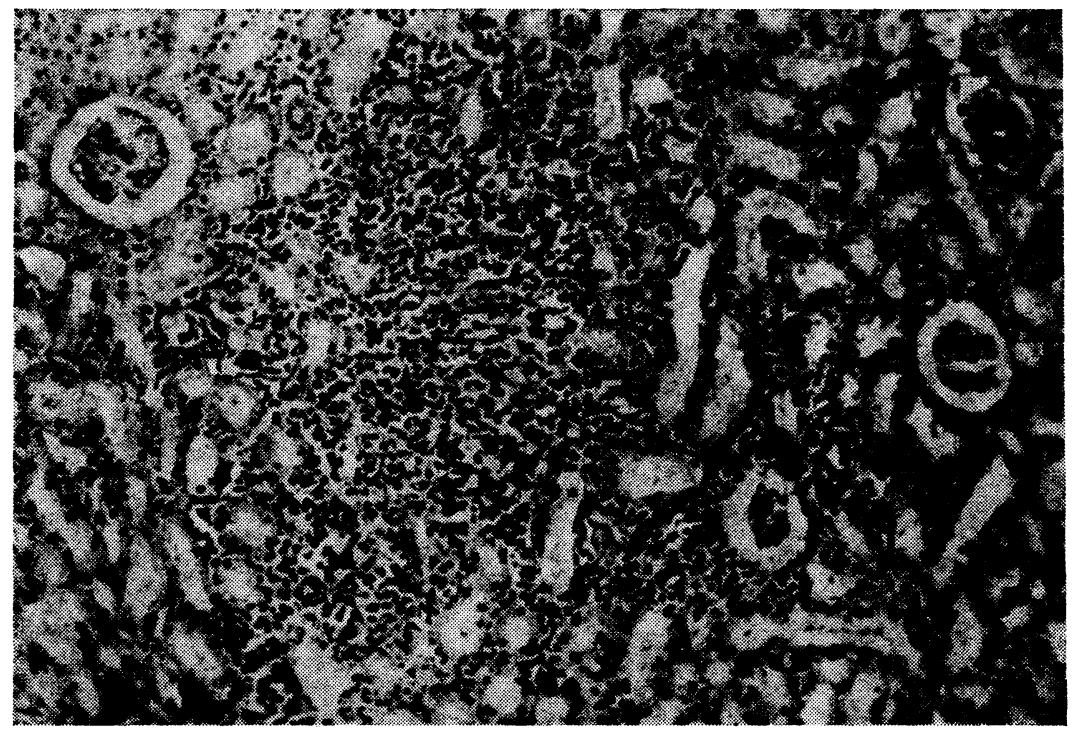

Fig. 10. Section of kidney showing lymphocytic infiltration in the interstitial tissue. H. \& E. $\times 70$.

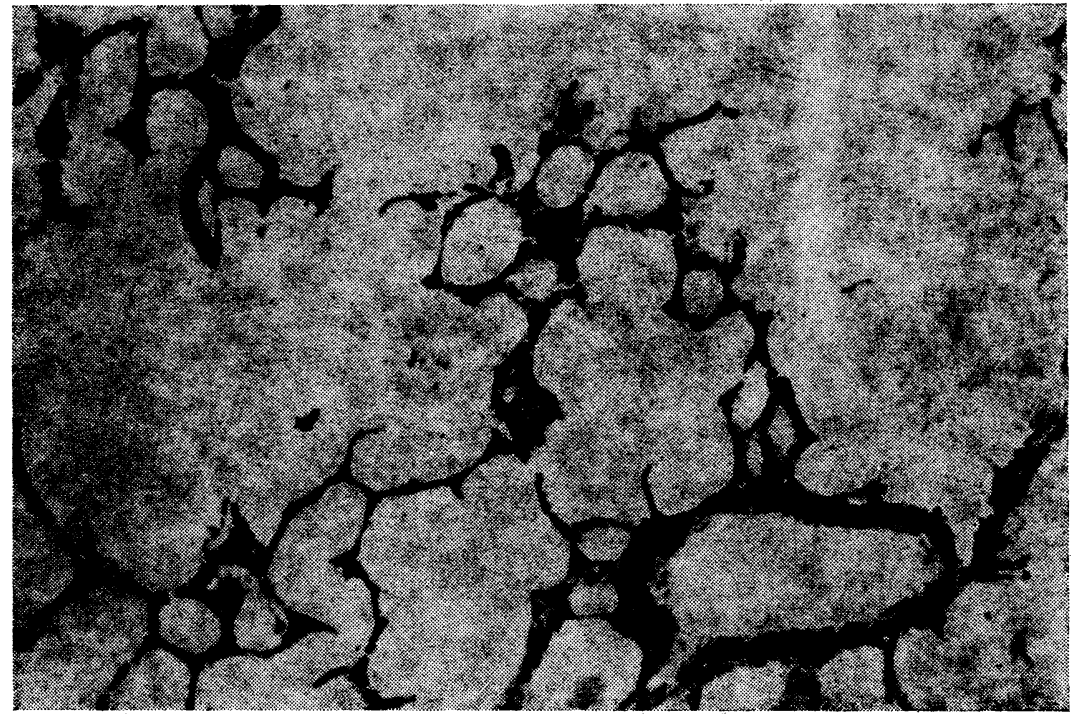

Fig. 11. Section of lung showing alveolar emphysema. H. \& E. $\times 70$. 


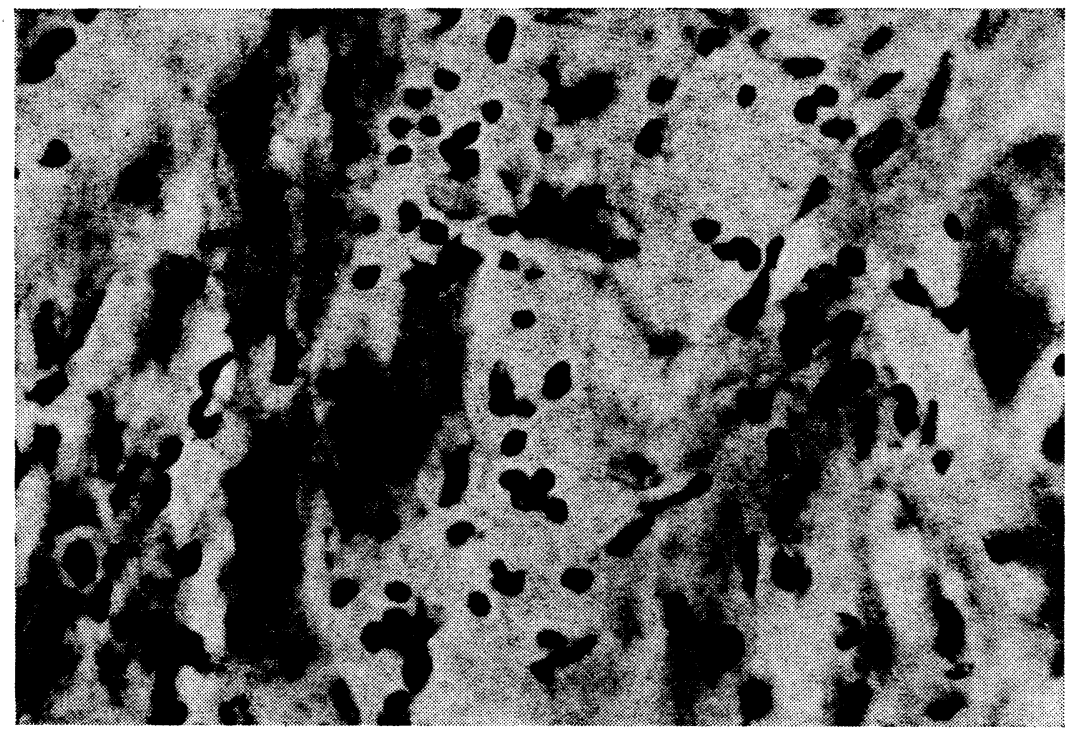

Fig. 12. Section of heart showing infiltration of lymphocytes in the myocardium. H. \& E. $\times 300$.

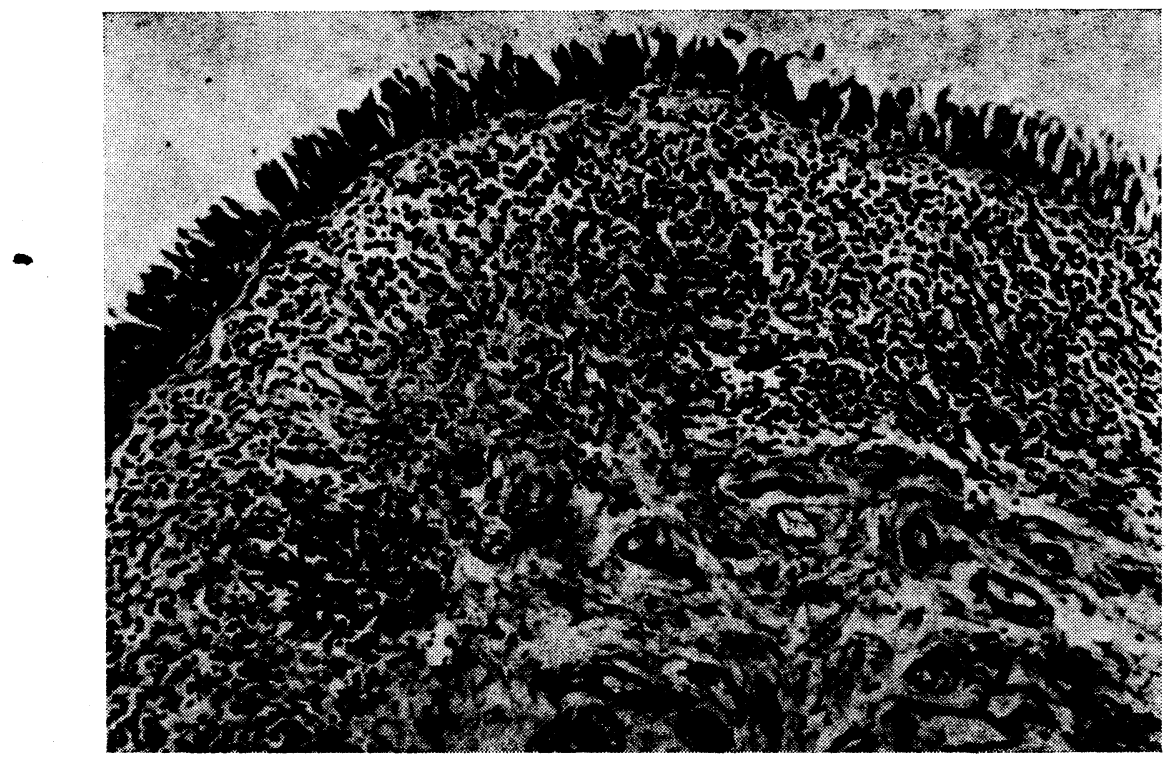

Fig. 13. Section of urinary bladder showing lymphocytic cystitis. H. \& E. $\times 70$. 
The histopathological changes recorded in other organs were foci of lymphocytic infiltration in the myocardium (Fig. 12), congestion in the pancreas, marked degree of lymphoid hyperplasia in the spleen and lymphocytic cystitis (Fig. 13).

The observations made in the macro- and microscopic lesions of different organs in buffalo calves which died following urea induced rumen alkalosis are similar to those reported by Clark et al. (1951), Morris and Payne (1970), Singer and McCarty (1971) and Dave (1980). These lesions are considered to be related to the cytotoxic effects developing due to chemical irritation of the cells by ammonium ions or free ammonia which passes across the cell membranes (Milne et al. 1958; Warren 1962). The pathological changes in the organs might also be related to tissue ischaemia and hypoxia occurring due to generalised venous congestion and marked increase in central venous pressure associated with failing cardiovascular and respiratory functions. Some of these changes might also be related to the accumulation of toxic metabolites circulating in the system following derangement in cellular metabolism.

\section{Acknowledgement}

Authors are grateful to the Indian Council of Agricultural Research, New Delhi for financing the project.

Klinické, biochemické a patologické změny při akutní alkalóze bachoru u telat buvolủ, vyvolané močovinou

Perakutní alkalóza bachoru byla vyvolána jednorázovým intraruminálním podáním močoviny $\mathrm{v}$ množství $1,25 \mathrm{~g} \cdot \mathrm{kg}^{-1}$ živé hmotnosti 6 zdravým býčkủm buvolů plemene Murrah, ve věku $1-2$ roky. Podání močoviny vyvolalo profúzní salivaci, zátěž bachorového metabolismu, nekoordinované pohyby, ulehnutí následované klonickými křečemi, jejichž frekvence se zvyšovala s postupem intoxikace. Dále byla pozorována dyspnoe, hyperpnoe, tachykardie, opisthotonus, dilatace pupil a během 60-150 minut zviŕata exitovala. Mezi dobou exitu a živou hmotností býčkủ byla při stejné dávce lineární závislost. Elektrokardiografická studie ukázala fibrilaci komor a přisouvání $P$ vlny $\mathrm{k} T$ vlně. Srdeční potenciály způsobily nahiodilé oscilace. Jaterní funkční testy byly výrazně ovlivněny. $\mathrm{V}$ prủběhu otravy došlo $\mathrm{k}$ vzestupu sérové aktivity arginázy, glutamát-oxalacetát-transaminázy, glutamát-pyruvát-transaminázy, laktát-dehydrogenázy a glutamát-dehydrogenázy se zvýšením poločasu bromsulfaleinu při exkrečním testu, což bylo následně potvrzeno histopatologickými nálezy. Histologické změny trávicího systému spočívaly $\mathrm{v}$ exfoliaci epitelu sliznice bachoru, lymfocytární abomasitidě a nekrotické enteritidě. Mezi ostatní významné histopatologické změny patřily folikulární cholecystitida, meningoencefalitida, lymfocytární nefritida a cystitida a alveolární emfyzém.

\section{Клинические, биохимические и патологические изменения при вызванном мочевиной остром алкалозе рубца у телят буйволов}

Острейший алкалоз рубца был вызван однократным интраруминальным применением мочевины в количестве 1,25 г.кт ${ }^{-1}$ живой массы 6 здоровым быкам буйволов породы Murrah в возрасте 1-2 года. Дача мочевины вызвала обильное слюновыделение, нагрузку механизма рубца, некоординированные движения, клонические судороги лежа, частота ко- 
торых увеличивалась с развитием интоксикации. Наблюдались также одышка, глубокое дыхания, тахикардия, опистотонус, расширение зрачков и летальный исход животных в течение 60-150 минут. Между леталыным исходом и живой массой быков при одинаковой дозе была установлена линейная завиоимость. Электрокардиографичеокие иоследования выявили мерцание предсердий и придвижение волны Р к волне Т. Потенциалы сердца вызвали случайную осцилляцию. Функцинальный анализ печени находился под явным влиянием. В ходе отравления произошло увеличение сывороточной активности аргиназы, глутамат-оксалацетат-трансаминазы, глутаматпируват-трансаминазы, лактат-дегидрогеназы и глутамат-детидрогеназы с увеличением полупериода бромсульфалеина при тесте выделения, что впоследствии подтвердил тистопатологический анализ. Гистологические изменения пищеварителыного тракта сводились с олущиванию эпителия слизистой рубца, лимфоцитарніому абомаситу и некротическому энтериту. $\mathrm{K}$ числу остальных важных гистопатологических изменений принадлежали фолликулярный холецистит, менингоэнцефалит, лимфоцитарный нефрит и цистит, альвеолярная эмфизема.

\section{References}

ALIKUTTY, K. M.: Effect of alkaline indigestion on rumen liquor, blood and internal organs with particular reference to liver functions in cattle and its therapy. $\mathrm{Ph}$. D. Dissertation, Punjab Agricultural University, Ludhiana, India, 1981.

BARTLEY, E. E. - DAVIDOVICH, A. D. - BARR, G. W. - GRIFFEL, G. W. - DAYTON, A. D. - DEYOL, C. W. - BECHTLE, R. M.: Ammonia toxicity in cattle. I. Rumen and blood changes associated with toxicity and treatment methods. J. Anim. Sci., 43, 1976: 835 -841.

BERGMEYER, H. U.: Methods of Enzymatic Analysis. 2 ed. Vol. I and II, Weinheim, Verlag Chemie, Academic Press, New York, London. 1974.

BLOOD, D. C. - RADESTITS, O. M. - HENDERSON, J. A. - ARUNDEL, J. H. - GAY, C. C.: Veterinary Medicine, VIth ed. ELBS and Baillière-Tindall, Eastbourne, U.K. 1983.

BUENO, L. - DOULOU, V. - CANDU, M.: Effects of ammonia on rumen motility in sheep. Ann. Biol. Anim. Biochem. Biophy., 17, 1977: 509-514.

CALLANAN, D. - DIXON, M. - WIDDICOMBE, J. W. - WISE, J. C. M.: Resp. Physiol., 22, $1974: 157$.

CHALUPA, W.: Problems of feeding urea to ruminants. J. Anim. Sci., 27, 1968: 207-219.

CHALUPA, W.: Metabolic aspects of non-protein nitrogen utilization in ruminant animals. Fed. Proc., 31, 1972: 1152-1164.

CHOUDHURI, P. C. - DAVE, M. R. - MISRA, S. K. - RANDHAWA, S. S.: Biochemical changes in the cerebrospinal fluid (CSF) in experimental urea toxicity in buffalo calves. Indian J. Vet. Med., 1, 1981: 27-31.

CLARK, R. - OYAERT, W. - QUIN, J. I.: Studies on the alimentary tract of the Merino sheep in South Africa. XXI. The toxicity of urea to sheep under different conditions. Onderstepoort J. Vet. Res., 25, 1951: 73 - 78.

COLES, E. M.: Veterinary Clinical Pathology. W. B. Saunders Company, Philadelphia. 1967.

CONWAY, E. J.: Microdiffusion Analysis and Volumetric Error, 4th ed. Crosby Lockwood and Son, London 1957.

CORNELIUS, C. E. - DOUGLAS, G. M. - GRONWALL, R. R. - FREEDLAND, R. A.: Comparative studies on plasma arginase and transaminases in hepatic necrosis. Cornell Vet., 53, 1963: $181-191$.

DAVE, M. R.: Studies on alkaline indigestion and its therapy in buffaloes. Ph. D. Dissertation, Punjab Agril. Univ. Ludhiana, India, 1980.

DAVIDOVICH, A. - BARTLEY, E. E. - CHAMPMAN, T. E. - BECHTLE, R. M. - DAYTON, A. D. - FRAY, R. A.: Ammonia toxicity in cattle. II. Changes in carotid and jugular blood components associated with toxicity. J. Anim. Sci., 44, 1977: 702-709.

HOFLUND, S.: Animal diseases associated with the use of deteriorated feeding stuffs under Swedish conditions. Vet. Bull., 37, 1967: 701 -717.

JOHNSON, A. E.: Tolerance of cattle to tansy ragwort (Senecio jacobaca). Am. J. Vet. Res., 39, 1978: $1542-1544$. 
KARSAI, F. - SCHAFER, M.: Diagnostic experiences with metabolic liver diseases of dairy cows. Mh. Vet.-Med., 39, 1984: 181-186.

KANEKO, J. J.: Clinical Biochemistry of Domestic Animals. 3rd ed. Academic Press, New York, 1980.

KIRKPATRICK, W. C. - ROLLER, M. H. - SWANSON, R. N.: Serum and tissue ammonium nitrogen and tissue water values in ammonia - intoxicated sheep. Am. J. Vet. Res., 33, 1972: $1187-1190$.

LLOYD, W. E.: Chemical and metabolic aspects of urea-ammonia toxicosis in cattle and sheep. Ph. D. Dissertation, Iowa Univ. Ames. 1970.

LUX, H. D.: Ammonium and chloride extrusion: Hyperpolarizing synaptic inhibition in spinal motorneurons. Sci., 173, 1971: 555-557.

MIA, A. S. - KOGER, H. D.: Direct colorimetric determination of serum arginase in various domestic animals. Am. J. Vet. Res., 39, 1978: 1381-1383.

MILNE, M. D. - SCRIBNER, B. H. - CRAWFORD, M. A.: Non-ionic diffusion and the excretion of weak acids and bases. Am. J. Med., 24, 1958: 709-729.

MISRA, R. K. - RANHOTRA, G. S.: Influence of energy levels on the utilization of peanut protein - urea nitrogen by cattle and buffalo. J. Amin. Sci., 28, 1969: 107-109.

MORRIS, J. G. - PAYNE, E.: Ammonia and urea toxicosis in sheep and their relation to dietary nitrogen intake. J. Agric. Sci. Camb., 74, 1970: 259-271.

NEDUNCHERALATHEN, B. - QUAYAM, S. A. - KATHIRESAN, D.: Serum GOT and SGPT activity in normal buffalo bulls. Livestock Advisor, 9, 1984: 3-4.

OLTJEN, R. R. - WALLER, G. R. - NELSON, A. B. - TILlMAN, A. D.: Ruminant studies with diammonium phosphate and urea. J. Anim. Sci., 22, 1963: 36-42.

PARKINS, J. J. - HEMINGWAY, R. G. - BROWN, N. A.: The increasing susceptibility of sheep to dietary urea toxicity associated with progressive liver dysfunction. Res. Vet. Sci., 14, 1973: $130-132$.

RAYMOND, S. - WILKINSON, J. H.: Clinical Chemistry: Theory and Practice, Academic Press, New York, London, 1969.

REITMAN, S. - FRANKEL, S.: A colorimetric method of determination of serum glutamic oxaloacetric and glutamic pyruvic transaminases. Am. J. Clin. Path., 28, 1957: 56-63.

ROSS, R. G.: An epidemiological study of fascioliasis in sheep. Vet. Rec., 80, 1967: 214-217.

SETHURAMAN, V. - RATHOR, S. S.: Pathological studies on acute acid and alkaline experimental indigestion in bovines. Indian Vet. J., 56, 1979: 831 -833.

SETIA, M. S. - SODHI, S. P. S. - RATTAN, P. J. S. - VERMAN, P. N.: Proceedings of the All India Symposium on Protein and NPN Utilization in ruminants, NDRI, Karnal, India. 1980.

SINGER, R. H. and McCARTY, R. T.: Pathological changes resulting from acute ammonium salt poisoning in sheep. Am. J. Vet. Res., 32, 1971: 1239-1246.

SMITH, R. H.: Reviews of the progress of Dairy Science. Section G. Nitrogen metabolism and the rumen. J. Dairy Res., 36, 1969: 313-331.

SUGAWARKA, H. - SASAKI, J.: Studies on the electroencephalogram in ruminants. III. Effect of experimental hyperammonemia in goats. Japanese J. Vet. Sci., 34, 1972: 79-80.

SVENDSEN, P.: Gastrointestinal atony in Ruminants. Royal Veterinary and Agric. University, Copenhagen, Denmark. 1973.

TURNER, A. W. - HODGETTS, V. E.: Buffer systems in rumen of sheep. Aust. J. Agric. Res., 6, 1955: 115-144.

VERMA, B. B. - GANAPATHY, M. S.: Studies on the blood histamine level in indigestion in bovines. Indian Vet. J., 50, 1973: 400-405.

WARREN, K. S.: Ammonia toxicity and pH. Nature, 195, 1962: 47-49.

WOOTTON, I. O. P.: Microanalysis in Medical Biochemistry. 5th ed. Jand A Churchill Ltd., London, 1964. 